\title{
The Capitalization Rate of Real Estate Property in Sleman District, Yogyakarta Province, Indonesia
}

\author{
Panji Kusuma Prasetyanto ${ }^{1)}$, Hadi Sasana ${ }^{2)}$ \\ ${ }^{1)}$ Faculty of Economics, Universitas Tidar \\ ${ }^{2)}$ Faculty of Economics and Business, Universitas Diponegoro \\ Corresponding Author: panjikusuma@untidar.ac.id
}

Recieved: May 2019 | Revised: June 2019 | Accepted: July 2019

\begin{abstract}
The objective of this study is to analyze the capitalization rate of real estate property in Sleman Regency, and its influential factors. This study will analyze the central tendency (mean) of capitalization rates for all housing areas and for each area. For the second objective, a few factors will be analyzedwhether they are statistically significant in influencing the real estate property capitalization rates in the study areas. A few factors that will be analyzed are: the assessment of the building, lot size, location, and age of the building. This study uses cross section data only from the prime source through a stratified sampling over 5 areas of luxurious housing complexes in Sleman District: Bale Agung, Bale Hinggil, Pondok Permai Kaliurang, Hyarta and Pesona Merapi. The empirical result of this analysis shows that the mean value of the capitalization rate of real estate property in the study areas is. From the result of the regression analysis, it can be known which variables or factorsare statistically significant in influencing the capitalization rate of the real estate property in the study areas. The result shows us that the assessment of the building, lot size, location, and the age of the building are statistically significant in influencing the capitalization rates of real estate property in the study areas.
\end{abstract}

Keywords: capitalization rate, building, size, location, age

JEL classification: R3, O1, Z3

How to Cite: Prasetyanto, P., \& Sasana, H. (2019). The Capitalization Rate of Real Estate Property in Sleman District, Yogyakarta Province, Indonesia. Jurnal Ekonomi Pembangunan: Kajian Masalah Ekonomi dan Pembangunan, 20(2). 141-152. doi:https://doi.org/10.23917/jep.v20i2.6885

DOI: https://doi.org/10.23917/jep.v20i2.6885

\section{Introduction}

Income capitalization is one of three approaches used in assessing properties, besides market data approach and cost approach. Capitalization rate uses mathematical methods, techniques, and procedures to analyze the ability of a property in generating income and to convert it into a net present value (NVP) with certain bank discounts (Appraisal Institute, 2008).

Sleman Regency is an area which is favored the most by new settlers who want to live in
Yogya Province. Its development is relatively faster than other regencies in the province. Some supporting factors for this development are the existence of top universities, the good conditions of the streets, and the existence of other facilities, such as schools, markets, hospitals, shopping complexes, shops, bus terminals, and other public facilities. These various factors have made Sleman Regency an interesting and promising area for property investments. 
The northern part of Sleman Regency, especially those around Kaliurang Street and Palagan Street, is a strategic and attractive location for the beauty of the scenery, so that many real estate property is built which are left empty by the owner. This real estate property is used by homeowners to be used as an investment to get income, one of which is by leasing.

In Sleman Regency, there has not been any institution which focuses specifically on investigating the returns of investment from rented real estate property, so investors still do not know how much their return of investment is exactly. Property appraisal in Indonesia, especially for very large property items such as real estate property rarely uses income capitalization due to lack of data gained from the capitalization rate.

In Sleman Regency there are a lot of real estate property especially around Kaliurang Street and Palagan Street because of it's location close to the city center, shopping centers, education centers, and close to health facilities, so this is the factor that causes some real estate property to be rented in that location, including in Bale Agung, Bale Hinggil, Pondok Permai Kaliurang, Hyarta and Pesona Merapi. The real estate property was chosen as a sample, because it is considered to represent the population of real estate property in Sleman Regency in terms of location factors around Kaliurang Street and Palagan Street.

Real estate property is generally used for private residences, but there are some real estate property that are rented out as residences. The amount of income from real estate property for rent, illustrates the rate of return on income from a number of property values. This income pattern is called the capitalization rate which shows the amount of "percentage" between net operating income and property value. The higher the capitalization rate produced by a property, the greater the ability of the property to generate annual income.

Sivitanidou \& Sivitanides (1999:297-332) used direct capitalization method to investigate the income capitalization rate of commercial properties like offices, warehouses, apartments, and shopping complexes. The study revealed that there were differences in the level of income capitalization in each type and location of properties due to permanent characteristics of the property and changes in the property market condition.

Chaney and Hoesli (2015) explained that the capitalization rate is an important metric for both real estate valuation and overall market assessments. Given that appraisal-based data are usually more readily available in many markets, but that such data have been criticized for their potential limitations. The location and refurbishment risks mainly capture variations at the micro level in both the risk premium and the expected NOI growth, they are easily diversifiable. Economic variables and potential variations in NOI growth at the macro level, on the other hand, are difficult if not impossible to diversify.

Several advantages of direct capitalization can be used as references in conducting deeper analyses on capitalization rates, especially concerning real estate property and the available data on market transactions and house rents in the Bale Agung, Bale Hinggil, Pondok Permai Kaliurang, Hyarta and Pesona Merapi complexes. Real estate property generally has a large area of land and buildings. The location of housing and the age of luxury residential buildings is also one factor in determining the choice of homeowners. Real estate property has been appropriate to describe the various factors that will be the object of research.

Based on the introduction above, there is an interesting situation that should be investigated, that previous research has factors that have not been studied related to its role on capitalization levels, especially real estate in Sleman Regency, Yogyakarta Province which is developing rapidly as a profitable investment with real estate rental income. These factors are lot size, building size, location, and age of the building, which can be formulated as follows, the capitalization rates of real estate property in Sleman Regency can first be analyzed by first looking at the normal property 
Jurnal Ekonomi Pembangunan: Kajian Masalah Ekonomi dan Pembangunan, 20 (2), 2019, 141-152

market values using market data comparison approach and the information of property rent rates as net operational income (NOI), with study objects located on Kaliurang Street, Palagan Street, and other surrounding areas (Kalimantan Street and Kapten Hariyadi Street), which are the locations of Bale Agung, Bale Hinggil, Pondok Permai Kaliurang, Hyarta,and Pesona Merapi complexes. Factors, such as lot size, building size, location, and building age, will be used as independent variables to see the influence to and correlations with the capitalization rates as the dependent variable, with study objects located inthe complexes of Bale Agung, Bale Hinggil, Pondok Permai Kaliurang, Hyarta, and Pesona Merapi.

An \& Deng (2009) conducted a study aimed at finding a more accurate model, which illustrates the degree of capitalization and expectations at the rate of return as well as the growth of rental properties, so that it can be used to predict future capitalization rates based on information on rates of return and growth rent of the past.

Frank (2013) in his study on property capitalization rates in Australia, with property objects such as offices, industries, and retails, showed that the capitalization rate in offices experienced the most significant increase in the last three years compared to industries and retails, while in this study, the writer focuses more on real estate property and the analysis of the impacting factors on the capitalization rates of those real estate property in Sleman Regency.

Investment is an act of spending money at present time with the purpose of gaining a return in the form of money or goods in the future. An investor has a purpose to gain a more or equally valuable return with the capital that has been invested which comprises 2 (two) components, the return of all capital that has been invested and the compensation for the property investment risk level (Zukriady, 2006: 8).

Property appraisal is a systematic process based on a valid procedure to get the value of a property. The appraisal has three approaches, namely cost approach, market data comparison approach, and income capitalization approach. Cost approach is an approach that identifies buildings to know the new building reproduction costs based on the newest standard rateand is adjusted with depreciation. Market data comparison approach is an approach that is carried out by comparing the appraised building with the same kind of building in which the adjustment will be seen from the comparison between the appraised building and its comparison property. Income capitalization approach is an approach that estimates properties based on the annual nett income of the capitalized properties with certain capitalization factors to gain the decent market value, which can be carried out withyield capitalization dan direct capitalization (Appraisal Institute, 2008).

Sivitanides, Torto, \& Wheaton, (2003: 45-53) examines the variation in the rate of capitalization of commercial property income with direct capitalization method, which results in consistency from previous research. The results of his research indicate there are differences in the rate of capitalization of income in each type and location of the property. The difference is influenced by 2 (two) property characteristic groups, namely: fixed and changing conditions of the property market.

Teate and Cherry (2009) explained that the advantages of direct capitalization, among others, are: it can give a picture to investors about the level of return that will be gained from the investment; it is simple and easy to implement and understand; it shows a reliable income; and it has a deeper usage. Direct capitalization is perfect to be applied in properties that have relatively stable NOI.

Joseph B.Nichols, (2013: 57) explained that the price indexes show a dramatic increase in both commercial and residential land prices over several years prior to their peak in 2006-2007 and a steep descent since then. These fluctuations have exceeded those in well-known indexes of home prices and commercial real estate prices. Because those indexes price a bundle of land and structures, this comparison implies that land 
Jurnal Ekonomi Pembangunan: Kajian Masalah Ekonomi dan Pembangunan, 20 (2), 2019, 141-152

prices have been more volatile than structures prices over this period. This result is a key element of the land leverage hypothesis, which holds that home prices and commercial property prices will be more volatile, all else equal, in areas where land represents a larger share of real estate value.

According to Pemenpera (2012) Republic of Indonesia's People Housing Ministerial Law Number 10 of Year 2012, real estate property are commercial houses with a selling price of four times bigger than simple houses. Simple houses are houses that are built on $60 \mathrm{~m}^{2}$ until $200 \mathrm{~m}^{2}$ pieces of land with a building size of at least 36 $\mathrm{m}^{2}$ and a price set by the government regulation.

Income capitalization approach is one of the three approaches, besides market data comparison approach and cost approach (Institute, 2008: 131). According to Zukriady (2006: 12), a housing property produces income from the nett rent, which is the rent of the property less its operational costs, using an income approach. The property value is gotten from the nett income capitalization with certain capitalization rates.

According to Supardi, Untung., Basuki, R.H., dan Lutfi (2010), property in terms of legal aspects is defined as a legal concept that includes interests, rights, and benefits associated with an ownership. Properties are grouped into several categories Real Property is the right of an individual or an entity to own or control the land and or building erected thereon. Personal Property (Personal Property) is any kind of property that is not permanent either in the form of tangible property (tangible property) such as: machine, equipment, and furniture; as well as intangible property such as: goodwill, trademark, and so on.

This study presents the study results as the following: (1) the amount of capitalization rates that can yield decent market values of real estate property located in the complexes of Bale Agung, Bale Hinggil, Pondok Permai Kaliurang, Hyarta, and Pesona Merapi; (2) the differences of capitalization rates in Sleman Regency, especially between real estate property located in Bale
Agung, Bale Hinggil, Pondok Permai Kaliurang, Hyarta, and Pesona Merapi, and those located outside those complexes; (3) factors that affect the capitalization rates of real estate property in Sleman Regency and the correlation of each factor with the capitalization rate, especially concerning houses located in the complexes of Bale Agung, Bale Hinggil, Pondok Permai Kaliurang, Hyarta, and Pesona Merapi.

\section{Research Method}

\subsection{Capitalization Rate Analysis}

Nett operational income is an effective gross income after deducted by total operational costs. Operational costs as annual costs which are spent continuously to increase the income and value of a property. Operational costs consist of fixed costs, variable costs, and replacement reserves (Appraisal Institute, 2008: 484-492).

To determine the overall capitalization rates of housing property, the simplest method can be used, which is the ratio between nett operational income (NOI) and the market value (MV). Where, real estate property capitalization rate () is annual nett income $\left(\mathrm{NOI}_{\mathrm{i}}\right)$ divided by market value or selling price $\left(\mathrm{MV}_{\mathrm{i}}\right)$.

The value of a property can be affected by these four main factors such as Social factor, Economic factor, Government factor, and Environmental factor. Social factor shown by several characteristics, such as population, education level, age, number of family members, work level, and crime level. Economic factor, shown by several characteristics such as average household income, per capita income, household income distribution, owner occupancy rate, property rent rate, property value rate, and number of development and expansion. Government factor, shown by various regulations issued by the government, politically and legally, that affect the property values, such as: property tax regulation, levels of development in by local governments in the forms of site pland and land use management, zoning, public facility quality, and environmental policies. Environmental factors, shown by several characteristics in 
Jurnal Ekonomi Pembangunan: Kajian Masalah Ekonomi dan Pembangunan, 20 (2), 2019, 141-152

valuing a property, such as: size, type and building maintenance, topography, the existence of rivers and open space, and transportation network indicating the accessibility of the particular area from other locations (Institute, 2008: 58-64).

The advantage of the method in this study is to have a better test result because it takes into account various factors that will affect the capitalization rate. The advantage is found in the analysis of the effect of variable land size, building size, building location, and building age on capitalization rates.

\subsection{Types and Sources of Data}

The data used in this study are primary data. The primary data were gotten from questionnaire, direct observations, and interviews. The questionnaire of this study was used as a measurement element by using market data comparison approach which was filled by the owners of the real estate property. Direct observations were carried out by the studyer himself to complete the appraisal process using the market data comparison approach. Interviews were conducted directly with the house owners to gain addition information, such as rent rates and other complementary data needed to appraise, using the market data comparison approach to gain the approximate market values of those real estate property.

Data collection in this study was conducted with a stratified sampling technique which is taking samples by looking at the strata of the samples on the population. The basis of sampling in this study is the location factor, which are luxurious complexes in two protocol streets: Kaliurang Street and Palagan Street, and in Kalimantan Street, and Kapten Hariyadi Street, referring to the regulation of Peraturan Menteri Perumahan Rakyat Republik Indonesia Nomor 10 Tahun 2012, which states that real estate property are commercial buildings with the selling price four time higher than simple houses. Meanwhile, simple houses are common houses that are built on land lots sizing $60 \mathrm{~m}^{2}$ until 200 $\mathrm{m}^{2}$ with building size of at least $36 \mathrm{~m}^{2}$ and selling prices set by the government.

This study uses the analysis of those factors affecting the property value to acquire a portrait of their influence on capitalization rate affecting a property value. The independent variables used in this study are: lot size (LT), building size (LB), location (LOK), and building age (UB), and the dependent variable is the capitalization rate $\left(R_{0}\right)$.

Functional form which is in line with the empirical model of this study is the Lin-Lin or double Log form model. Gujarati (2003: 564) stated that this model is used to see the influence and connection between the independent variables and the dependent ones to assume that there is a connection between both variable types. In reality, however, the data used do not always have a liner connection. Based on this then, the formulation is described as follows: $R_{0}$ $=B_{0}+B_{1} \mathrm{LT}+B_{2} \mathrm{LB}+B_{3} \mathrm{LOK}+B_{4} \mathrm{UB}+\mu$. Where, capitalization rate becomes the dependent variable and the independent variables of this study are land size, building size, building location, and building age.

Table 1. Population and Sample Real Estate Property in Sleman District

\begin{tabular}{lccl}
\hline \multicolumn{1}{c}{ Location } & Population & Sample & \multicolumn{1}{c}{ Note } \\
\hline Kaliurang Street & 99 & 20 & $\begin{array}{l}\text { Bale Hinggil and Pondok } \\
\text { Permai Kaliurang } \\
\text { Palagan Street }\end{array}$ \\
$\begin{array}{l}\text { Kalimantan Street dan Kapten } \\
\text { Haryadi Street }\end{array}$ & 260 & 10 & $\begin{array}{l}\text { Komplek Hyarta } \\
\text { Komplek Bale Agung dan } \\
\text { Pesona Merapi }\end{array}$ \\
\hline
\end{tabular}


The calculation of capitalization rates of those real estate property uses a direct capitalization method, which is comparing the nett operational income as the portrayal of nett rent income with the market prices of the real estate property. The process of property income capitalization can be divided into three (3) levels: 1) potential gross income is the income in the a condition when the property can all be rented at a market rent, 2) effective gross income is the level of potential gross income after being deducted by the vacant level and uncollectible rents, and 3) nett operational income (NOI) is the level of effective gross income after being deducted by operational costs.

Operational costs consist of fixed costs (annual property tax), variable costs (building maintenance), replacement reserves, and management fee, which are annual costs continually spent to increase the property income and value (Institute, 2008: 481-492).

Market value is transactions that happen decently in a condition where the buyer and seller do a transaction without any force, there is enough time to transact, there is clear and complete market information of the transacted property, and there is no consideration for special offers due to certain conditions. The market values in this study were gained from the appraisal estimates using market data comparison approach.

Market data comparison approach is an approach that is carried out to compare the appraised property with other similar properties which are of the same kind, similar, and the best, so that an adjustment can be made from the results of the comparison.

\subsection{Limitation and Operational Definitions}

The limitation and operational definitions of this study are only on data that fulfill the criteria in line with the study objective so that there will not be misperception in analyzing the results of this study. The limitation and operational definitions such as capitalization rate is the percentage used to convert the future income estimate to be the present value. capitalization rate in this study is the ratio between annual income from the property's rent earned by the owner and the market value. Another limitation in this studies are an annual nett income earned by the owner from the renter of the real estate property. The rent rate is gotten from the list of rented land and houses during the study and through surveys to similar adjacent houses. Market value is the decent transaction value that occurs when the buyer and the seller do a transaction without any force, have plentiful time to transact, have and complete information about the property, and do consider special offers due to certain conditions. The market value in this study is gotten from the appraisal estimate using market data comparison approach. Land size is the size of the property land measured in square meter $\left(\mathrm{m}^{2}\right)$. Building size is the total size of the building measured in square meter $\left(\mathrm{m}^{2}\right)$. The locations in this study are the groupings of the study objects in several areas. The building age in this study is gotten from the beginning of the building was built until at the time of the study, stated in years. According to the Regulation of Peraturan Menteri Perumahan Rakyat Republik Indonesia Nomor 10 Tahun 2012, real estate property are commercial houses with the selling price four (4) times bigger than simple houses. Simple houses are common houses built on land sizing $60 \mathrm{~m}^{2}$ until $200 \mathrm{~m}^{2}$ with building size of at least $36 \mathrm{~m}^{2}$ and the selling prices should be regulated by the government.

\subsection{Data Validation}

Data validation is carried out to check the data as well as the field information by organizing them statistically so that the results are complete and can portray the condition nearest to the real situation to produce unbiased and valid calculation. These collected data were used to find out the capitalization rates of the real estate property and how big the influence of land size, building size, location, and building age was towards the real estate property capitalization rates in Sleman Regency, especially in the complexes of Bale Agung, Bale Hinggil, Pondok Permai Kaliurang, Hyarta, and Pesona Merapi. 
Jurnal Ekonomi Pembangunan: Kajian Masalah Ekonomi dan Pembangunan, 20 (2), 2019, 141-152

\section{Results and Discussion}

\subsection{Results}

The analysis of capitalization rate calculations covers the calculation of the capitalization rate of each sampling object and the central tendency measurement of all the real estate as well as each complex.

\subsection{Capitalization Rate Calculations}

The capitalization rates in Sleman Regency, especially in five housing complexes of Bale Agung, Bale Hinggil, Pondok Permai kaliurang, Hyarta, and Pesona Merapi have various rates, ranging from $3 \%$ to $5.2 \%$. The lowest capitalization rate (3\%) was found in Pesona Merapi and the highest (5.2\%) was in Bale Hinggil. The results of this study about the capitalization rates in those 5 (five) housing complexes are similar with the results of study conducted by Hastuti (2005) who studied 5 (five) complexes of Casa Grande, Nandan Griya Idaman, Griya Mahkota, Tirtasani, and Merapi View which had capitalization rates from 2.8\% until $5.4 \%$.

\subsection{Regression Result Analysis}

Regression analysis was carried out to find out what factors had influenced the capitalization rates of the real estate property in this study. This study used the linear model with $95 \%$ degree of freedom. The independent variables are: lot size, building size, location, and building age. Capitalization is the dependent variable. The significance between the independent variables and the dependent one will be analyzed for the regression, with a linear function model.

Regression analysis was carried out to find out what factors influenced the capitalization rates of those real estate property. This study used the linear model with the confidence level of 95\%. The independent

variables are: land size, building size, location, and building age, and the dependent variable is the capitalization rates. The significance between the independent variables and the dependent one was further analyzed for the regression using the linear function model. The regression analysis was on the variables of land size, building size, location, and building age, and their influence on the capitalization rates as the dependent variable. The best empirical model used in this study is the Lin-Lin model which can be seen in Table 2.

The regression results in Table 2 state that the land size variable has a positive influence to the capitalization rate. The bigger the land is, assuming that other variables do not change (ceteris paribus, the higher the capitalization rate will be, meaning that a piece of land with the size of $1 \mathrm{~m}^{2}$ has a capitalization rate of about 2.07E-05 which is inline with the regression coefficient.

The building size variable also has a positive and significant relation assuming that other variables do not change (ceteris paribus), then a building with the size of $1 \mathrm{~m}^{2}$ has a capitalization rate of $2.22 \mathrm{E}-05$ which is inline with the regression coefficient.

Table 2. Summary of Regression Result Analysis

\begin{tabular}{ccc}
\hline Variable & Coefficience & t-statistical results \\
\hline C & 0.021 & 8.219 \\
LT & $2.07 \mathrm{E}-05$ & 2.041 \\
LB & $2.22 \mathrm{E}-05$ & 2.065 \\
LOK & 0.003 & 4.180 \\
UB & 0.001 & 3.279 \\
$\mathrm{R}^{2}$ & 0.603 & \\
F-Statistics & 17.118 & \\
\hline
\end{tabular}


The third variable, location, also has a positive and significant relation with the capitalization rates which also shows that the capitalization rates in those five housing complexes (Bale Agung, Bale Hinggil, Pondok Permai kaliurang, Hyarta, and Pesona Merapi) are varied, with a regression coefficient of 0.003 , indicating that real estate property with location code 1 bigger has higher capitalization rate of about 0.003, assuming that other variables areceteris paribus.

The fourth variable, building age, also has a positive and significant relation with the capitalization rate. In all five luxurious housing complexes in Sleman Regency, the older the buildings are the capitalization rate increases by 0,001 per year. The reason is that is there is a significant additional value from the land size and the building size in all those five complexes from the start of the building development or from the start of the house purchase up until now. So, the older the building is, the more capitalization rate it produces, along with the increasing property investment value the real estate property has.

The details in Table 2 show that all the four variables are located in the rejected area of $\mathrm{H}_{0}$, so it can concluded that the variables of land size, building size, location, and building age have significant, meaningful, and real relationships with the dependent variable which is the capitalization rates. These four variables have a meaningful influence on every change of the capitalization rates in the luxurious housing complexes of Bale Agung, Bale Hinggil, Pondok Permai Kaliurang, Hyarta, and Pesona Merapi.
With $\alpha=0.05, \mathrm{k}-1=5-1=4$, and $\mathrm{n}-\mathrm{k}=50-5$ $=45$, the F-table gotten is 2.58 . The regression analysis result achieved $\mathrm{F}$-value amounting to 17.118, while the F-table is 2.58 , which means that $\mathrm{F}$-value $>\mathrm{F}$-table, so the $\mathrm{H}_{0}$ is rejected which means that the independent variables (land size, building size, location, and building age) altogether could explain significantly the changes that occur to the dependent variable (capitalization rates).

This test was used to see if the independent variables could explainaltogether the phenomena that happened to the dependent variable, or in other words, to see how big the influence of the independent variables to the dependent variable was. The result of the regression analysis with determinant coefficient $\left(R^{2}\right)$ was 0.603 , which means that the independent variables could explain around $60 \%$ of the factors affecting the dependent variable, or in other words, it could explain quite highly about the phenomena.

The classic assumption test results show that there is no multicollinearity test, heterocedasticity test, auto correlation test and normality test. The conclusion in this research model is blue

\subsection{Discussion}

The result of the regression and tests in this study, it can be concluded that the variables of land size, building size, location, and building age have a significant influence statistically on the capitalization rates of the real estate property in all five complexes. From the result of regression analysis in this study, the matching mathematic model or equation is the following:

$\begin{array}{lllll}\text { Ro } & =0.021+2.07 \mathrm{E}-05 \mathrm{LT}+2.22 \mathrm{E}-05 \mathrm{LB}+0.003 \mathrm{LOK}+0.001 \mathrm{UB} \\ \text { t-stat } & =(8.219) & (2.041) & (2.065) & (4.180) \\ \text { Stand. } E & =(0.003) & (1.02 \mathrm{E}-05) & (1.08 \mathrm{E}-05) & (0.001) \\ \mathrm{R}^{2} & =0.603=60.3 \% \\ \text { F-stat } & =17.118\end{array}$


Based on the above equation, the interpretations are as follows:

The land size variable has a positive effect on the capitalization rates. The bigger the land is, assuming that other variables remain the same (ceteris paribus), the higher the capitalization rate is. A real estate property with a land size of $1 \mathrm{~m}^{2}$ will have a capitalization rate of $2.07 \mathrm{E}$ 05 which is inline with the regression coefficient produced. This result is similar with the study conducted by Hastuti, (2005) who stated that the land size has a significant influence towards the capitalization rates, especially those of real estate property. Larson, (2015: 1) explained that land is an important and valuable natural resource, serving both as a store of wealth and as an input in production. Previous attempts to measure the value of land of the United States have focused on indirect measures, inferring values based on the difference between the market value of real property and the replacement value of structures, and have not counted the entirety of the land area of the United States. Instead, this paper takes hedonic estimates of land prices in various locations and interpolates these values to a mosaic of parcels, census tracts, and counties of various sizes in the contiguous (lower 48) United States plus the District of Columbia. Estimates suggest that this 1.89 billion acres of land are collectively worth approximately $\$ 23$ trillion in 2009 (current prices), with $24 \%$ of the land area and $\$ 1.8$ trillion of the value held by the federal government.

As with the building size variable, it also has a positive effect on the capitalization rates. The bigger the building is, assuming that other variables remain the same (ceteris paribus), the higher the capitalization rate is. A real estate property with a building size of $1 \mathrm{~m}^{2}$ will have a capitalization rate of $2.22 \mathrm{E}-05$ which is inline with the regression coefficient produced. This is different from the view of Kamiston (2006) measuring statistically instruct the link and the significant variable influence to capitalization rate of retail property in Depok, and to measure the difference mount the capitalization rate of retail property which are concentrated in Gejayan and Kaliurang street and which concentrated of outside two street that,There are factors influencing capitalization rate and good have the character such as space of building, age of building use, wide of front, lease terms, electricity facility and location. Cross section data used industri-industri this research come from purposed sampling on several building store property in depok Municipality. There are 60 sample used industri-industri this research. Data collection are primary data from field research which are lease time data, store location, price selling data, and secondary data from Property tax office. Analysis method used in this research are statistic analysis that use to measuring central tendention, normality of distribution, and than conduct two of avareges test to show capitalization rate differences on diferent store property location. Next analysis is using double linear regression analysis to know the influence of factors which mention above The result of research indicate that the mean of capitalization rate of retail property is equal to $22 \%$ with the variation between $14.72 \%$ up to $32.26 \% \%$ and have the normal distributed Mean of capitalization rate in central city higher location equal to $1.605 \%$ compared to outside central city location, Through analysis regresi obtained result that variables are space of building, age of building use, wide of front, lease terms, electricity facility and location space of building, age of building use, wide of front, lease terms, electricity facility and location to have the influence which significant with the Lin-Lin estimate model with explanation power (R2 who said that the building size variable has a negative influence on the capitalization rates, which in this case, were in the form of shopping complexes.

In the location variable, it also has a significant and positive relation with the capitalization rates; nonetheless, the real estate property in Sleman Regency, especially those located in 5 (five) housing complexes of Bale Agung, Bale Hinggil, Pondok Permai Kaliurang, Hyarta, and Pesona Merapi have various capitalization rates with a regression coefficient of $\mathbf{0 . 0 0 3}$ which indicates 
Jurnal Ekonomi Pembangunan: Kajian Masalah Ekonomi dan Pembangunan, 20 (2), 2019, 141-152

that the luxurious properties that have bigger than 1 location code will have capitalization rates of 0.003 bigger, assuming that other variables are ceteris paribus. The location variable in this study is categorized into three locations/areas out of the five housing complexes in Sleman Regency. Complexes located in areas other than in Kaliurang Street and Palagan Street (Bale Agung and Pesona Merapi) have the location attribute code of zero (0). Complexes located in Kaliruang Street (Bale Hinggil and Pondok Permai Kaliurang) have the location attribute code of one (1). Complex located in Palagan Street (Hyarta) has the location attribute code of two (2).

This grouping is based on several aspects, such as areas, location characteristics, and the results of t-test on the three locations which showed a significant difference among these three housing complex locations. The regression result shows that the location factor has a significant impact on the capitalization rate with the t-stat of 4.180 and a coefficient of 0.003 . This means that the housing complex in Palagan Street has a capitalization rate of 0.003 bigger than those located in Kaliurang Street, while the complexes in Kaliurang Street have a capitalization rate of 0.003 bigger than the complexes not located in Kaliurang Street nor in Palagan Street. These findings are inline with the study by Lust (1997: 26) who argued that humans will always act efficiently in making location as the main factor in choosing a property with considerations such as the easy access to the city center, educational facilities, and shopping places.

In the variable of building age, it also has a significant and positive relation with the capitalization rates. All five luxurious housing complexes in Sleman Regency showed that as the building age is in the multiplication of one year, the capitalization rate will be 0.001 higher. The reason why the building age has a positive and significant relation is because of the addition of values form land size and building size. So, the older the houses are, the higher the capitalization rates will be, along with the increase in in the property investment values in those five luxurious housing locations in Bale Agung, Bale Hinggil, Pondok Permai Kaliurang, Hyarta, and Pesona Merapi. This finding about the influence of the building age factor towards the capitalization rates was not found in the study by Hastuti (2005) who only investigated the land size, building size, and building age.

\section{Conclusions}

The northern part of Sleman Regency is a strategic and attractive location for the beauty of the scenery, so that many real estate property is built which are left empty by the owner. This real estate property is used by homeowners to be used as an investment to get income, one of which is by renting out, so the research requires home owners to calculate the capitalization rate. The calculation of capitalization rates of those real estate property uses a direct capitalization method, which is comparing the nett operational income as the portrayal of nett rent income with the market prices of the real estate property.

Based on the discussions of the results of this study about the capitalization rates of real estate property in Sleman Regency, in particular those located in five real estate of Bale Agung, Bale Hinggil, Pondok Permai Kaliurang, Hyarta, and Pesona Merapi, it can be concluded that the capitalization rates of real estate property in Sleman Regency, especially in Bale Agung, Bale Hinggil, Pondok Permai Kaliurang, Hyarta, and Pesona Merapi have the mean of 4.029, which means that when someone has a luxurious property and expects to earn an annual income from that property, could be around $4.029 \%$ gathered and tabulated of the value of the luxurious property.

The results of this study show that the factors that affect the capitalization rates as the dependent variable in 5 (five) luxurious housing complexes in Sleman Regency, after being analyzed with regression analysis, are land size, building size, location, and building age. Based on t-statistical test, these four variables rejected the $\mathrm{H}_{0}$, so it can be concluded that they have a significant and real correlation with the dependent variable, which 
Jurnal Ekonomi Pembangunan: Kajian Masalah Ekonomi dan Pembangunan, 20 (2), 2019, 141-152

acts as the dependent variable. F-statistical test earn an F-value of 17.118 , while the F-table is 2.58, which means that F-value $>\mathrm{F}$-table, so $\mathrm{H}_{0}$ is rejected, meaning that the four independent variables altogether can explain significantly the changes in the dependent variable (capitalization rate).Determinant Coefficient Test $\left(R^{2}\right)$ after the regression analysis earns a determinant coefficient $\left(\mathrm{R}^{2}\right)$ of 0.603 , which means that the independent variables can explain about $60.3 \%$ of the factors that influence the dependent variable. The results of regression analysis on factors that affect the capitalization rates of real estate property in Sleman Regency, especially in five housing complexes, are interpreted that land size variable has a positive effect on the capitalization rates. This result is similar with the study conducted by Hastuti, (2005) who stated that the land size has a significant influence towards the capitalization rates, especially those of real estate property. the building size variable, it also has a positive effect on the capitalization rates. This is different from the view of Kamiston C, (2006)measuring statistically instruct the link and the significant variable influence to capitalization rate of retail property in Depok, and to measure the difference mount the capitalization rate of retail property which are concentrated in Gejayan and Kaliurang street and which concentrated of outside two street that,There are factors influencing capitalization rate and good have the character such as space of building, age of building use, wide of front, lease terms, electricity facility and location. Cross section data used industri-industri this research come from purposed sampling on several building store property in depok Municipality. There are 60 sample used industri-industri this research. Data collection are primary data from field research which are lease time data, store location, price selling data, and secondary data from Property tax office. Analysis method used in this research are statistic analysis that use to measuring central tendention, normality of distribution, and than conduct two of avareges test to show capitalization rate differences on diferent store property location. Next analysis is using double linear regression analysis to know the influence of factors which mention above The result of research indicate that the mean of capitalization rate of retail property is equal to $22 \%$ with the variation between $14.72 \%$ up to $32.26 \% \%$ and have the normal distributed Mean of capitalization rate in central city higher location equal to $1.605 \%$ compared to outside central city location, Through analysis regresi obtained result that variables are space of building, age of building use, wide of front, lease terms, electricity facility and location space of building, age of building use, wide of front, lease terms, electricity facility and location to have the influence which significant with the Lin-Lin estimate model with explanation power ( $\mathrm{R} 2$ who said that the building size variable has a negative influence on the capitalization rates. The location variable, it also has a significant and positive relation with the capitalization rates. These findings are inline with the study by Lust (1997: 26)who argued that humans will always act efficiently in making location as the main factor in choosing a property. the variable of building age, it also has a significant and positive relation with the capitalization rates. This finding about the influence of the building age factor towards the capitalization rates was not found in the study by Hastuti (2005) who only investigated the land size, building size, and building age.

This study has important practical implication for helping property investors and property agents in making investment decisions. This research can be used to find out which locations have high returns in Sleman Regency. Recommendations for further research that discusses the factors that capitalization rate of real estate property, in order to further add to the independent variables that influence it. The limitation in this study is the amount of data obtained as many as 50 samples from 5 (five) real estate property complexes, so that further samples can be added to the next sample in order to obtain more accurate results. This limitation was caused by the difficulty of getting into elite housing that implements limited areas for outsiders. 


\section{References}

An, X., \& Deng, Y. (2009). A structural model for capitalization rate. Real Estate Research.

Chaney, A., \& Hoesli, M. (2015). TransactionBased and Appraisal-Based Capitalization Rate Determinants. International Real Estate Review, 18(1), 36-37.

Frank, K. (2013). cap rate analysis post areit reporting season Commercial Property Insight. (March).

Gujarati, D. (2003). Ekonometri Dasar. Terjemahan: Sumarno Zain. Jakarta: Erlangga.

Hastuti, S. (2005). Analisis Tingkat Kapitalisasi Perumahan Mewah di Kabupaten Sleman (Magister Ekonomika Pembangunan UGM). Retrieved from http://etd.repository. ugm.ac.id/index.php?mod=penelitian_detail\&sub=PenelitianDetail\&act=view\& typ=html\&buku_id=30670\&obyek_id=4

Appraisal Institute. (2008). The Appraisal of Real Estate 13th Edition (13th ed.). Chicago.

Nichols, J. B., Oliner, S. D., \& Mulhall, M. R. (2013). Swings in commercial and residential land prices in the United States. Journal of Urban Economics, 73(1), 57-76

Kamiston C, B. (2006). Analisis Tingkat Kapitalisasi Proprerti Pertokoan di Kecamatan Depok Kabupaten Sleman. Retrieved from http://etd.repository.ugm.ac.id/index.php?mod=penelitian_detail\&sub=PenelitianDetail\&act=view\&typ=html\&buku_id=30578

Larson, W. (2015). New Estimates of Value of Land of the United States. Bureau of Economic Analysis, 1. Retrieved from http:// large.stanford.edu/courses/2016/ph240/ troutman1/docs/larson_2015.pdf

Lust, K. M. (1997). Real Estate Valuation Principles and Application. USA: IRWIN.

Luten L. Teate, John W. Cherry, Jr., \& K. B. D. (2009). Apitalization ate nalysis. (770).

Pemenpera. (2012). Republic of Indonesia's People
Housing Ministerial Law Number 10 of Year 2012. (1946), 1-28.

Sivitanides, P. S., Torto, R. G., \& Wheaton, W. C. (2003). and Asset Pricing. Office, 45-54.

Sivitanidou, R., \& Sivitanides, P. (1999). Office Capitalization Rates: Real Estate and Capital Market Influences. Journal of Real Estate Finance and Economics, 18(3), 297-322. https://doi. org/10.1023/A:1007780917146

Supardi, Untung., Basuki, R.H., dan Lutfi, A. M. (2010). Tinjauan Konsep Prosedur Teknik Penilaian dan Properti. Jakarta: Mitra Wacana Media.

Zukriady, E. (2006). Analisis Tingkat Kapitalisasi Rumah Toko di Kecamatan Pangkalan Kerinci Kabupaten Pelalawan Provinsi Riau (Magister Ekonomika Pembangunan UGM). Retrieved from http://etd.repository. ugm.ac.id/index.php?mod=penelitian_detail\&sub=PenelitianDetail\&act=view $\&$ typ=html\&buku_id=33405 